\title{
Facilitation of retrieval by d-amphetamine following anisomycin-induced amnesia
}

\author{
DAVID QUARTERMAIN and HARVEY J. ALTMAN \\ Division of Behavioral Neurology School of Medicine, New York University, New York, New York
}

\begin{abstract}
A durable amnesia for an inhibitory avoidance response was induced in mice by an immediate posttraining injection of the protein-synthesis inhibitor anisomycin. Different groups were injected, immediately after training or $30 \mathrm{~min}$ prior to testing, with various doses of d-amphetamine in an attempt to alleviate the amnesia. Results indicated that, while immediate posttraining treatments were ineffective, substantial recovery of memory occurred when d-amphetamine $(.5,1.0$, and $2.0 \mathrm{mg} / \mathrm{kg}$ ) was administered before testing. Additional experiments showed: (1) that amphetamine-induced facilitation of avoidance was specific for the situation in which training occurred and thus could not be attributed to nonspecific effects of acute amphetamine treatment and (2) that enhanced avoidance could not be produced by pentylenetetrazol, strychnine, or noncontingent footshock. Amnesia could also be reversed by pretest treatment with methylphenidate (15 and $20 \mathrm{mg} / \mathrm{kg}$ ). Administration of the amphetamine analog 4-hydroxyamphetamine, which principally releases peripheral catecholamines, failed to reverse the amnesia. These findings add to the growing body of evidence that suggests that catecholamines are involved in memory retrieval processes.
\end{abstract}

Relatively little research in animal amnesia has been devoted to the analysis of retrieval mechanisms. This is in large measure a consequence of the dominance of the consolidation hypothesis, which has focused attention exclusively on events taking place during and shortly following acquisition. Recently, however, interest has developed in the study of retrieval processes and the neural mechanisms that underlie them. This interest can be attributed to the existence of a growing body of data that indicate that retrieval failure is an important source of forgetting (e.g., Lewis, 1979; Quartermain, 1972b; Spear, 1976) and also to the development of a theoretical framework (Spear, 1976, 1978) within which the data can be integrated (Deweer, Sara, \& Hars, 1980; Mactutus, McCutcheon, \& Riccio, 1980).

Almost nothing is known about the neural mechanisms that underlie retrieval of stored memories. The commonly expressed view that information is likely to be encoded redundantly in a large aggregates of neurons distributed throughout the brain implies that the process of retrieval involves coordinated neural activity in widely dispersed anatomical regions. The structures that mediate this neural activity and the mechanisms that are involved remain unknown. Potential clues regarding possible neural

This research was supported by Grant NS-12633 from the National Institute of Neurological and Communicative Disorders and Stroke. The first author's complete mailing address is: Division of Behavioral Neurology, School of Medicine, New York University, 341 East 25th Street, New York, New York 10010. The second author is now at: Lafayette Clinic, $951 \mathrm{E}$. Lafayette Avenue, Detroit, Michigan 48207. mechanisms are provided by the results of some recent pharmacological investigations that suggest that central monoamine transmitter systems may play a significant role in the retrieval of stored memories (Quartermain, 1976; Quartermain, 1982b). Two sources of evidence support such a function: (1) It has been shown that treatment with agents that inhibit norepinephrine (NE) synthesis prior to testing disrupt retention in both rats and mice (Hamburg \& Cohen, 1973; Kurtz \& Palfai, 1978; Randt, Quartermain, Goldstein, \& Anagnoste, 1971); (2) pretesting administration of pharmacological agents that increase catecholamine (CA) activity can alleviate experimentally induced amnesias (Freedman, Bachman, \& Quartermain, 1979; Quartermain \& Botwinick, 1975b; Quartermain, Freedman, Botwinick, \& Gutwein, 1977) and retard normal forgetting (Quartermain, 1982b; Quartermain \& Botwinick, 1975a). These findings suggest that release of central CAs may be involved in the neural processes that underlie retrieval.

The intention of the present study was to obtain further information on the role of CAs in retrieval mechanisms by determining whether stimulation of CA activity by d-amphetamine prior to the retention test would reverse the amnesia induced by the inhibition of protein synthesis. Amnesia paradigms provide a useful technique for investigating mechanisms underlying memory retrieval (Mactutus, McCutcheon, \& Riccio, 1980; Quartermain, 1982b). Retention loss can be rapidly induced, and the effectiveness, as retrieval facilitators, of pharmacological agents or behavioral treatments delivered prior to the retention test can be evaluated by the extent to 
which they relieve the amnesia. Several previous studies have shown that d-amphetamine administered prior to the retention test can enhance retention. For instance, it has been shown that amnesia induced by pretraining cycloheximide (CXM) for a multiple-trial food-motivated spatial-discrimination task could be alleviated by d-amphetamine $(1 \mathrm{mg} / \mathrm{kg})$ administered $1 \mathrm{~h}$ prior to the retention test (Quartermain \& Botwinick, 1975b). Because d-amphetamine is known to release NE and dopamine (DA), as well as to block reuptake of both of these amines, these data suggest a role for the CAs in retrieval processes.

In order to demonstrate that pretesting treatments improve performance by facilitating retrieval processes, it is necessary to show that such treatments are not exerting their effects by inducing new learning or by enhancing motivation. These hypotheses have been extensively tested as alternative explanations for the retention enhancement induced by behavioral reactivation treatments and have been shown to be inadequate to account for the full range of effects of these treatments on retention. (See Gordon, 1981, and Spear, 1978, for summaries of these studies.) These alternative explanations also inadequately account for the retention enhancement induced by pretest administration of pharmacological agents (e.g., Quartermain \& Botwinick, 1975b; Quartermain et al., 1977), although the issue has not received extensive investigation.

The objectives of the present study can be summarized as follows: (1) to determine whether a durable amnesia induced by protein-synthesis inhibition can be alleviated by d-amphetamine administered either immediately posttraining or $30 \mathrm{~min}$ before testing; (2) to ascertain whether another agent (methylphenidate), which releases CAs by a mechanism different from that of amphetamine, can similarly alleviate the amnesia; (3) to evaluate the specificity of the effect of amphetamine on retention processes and to investigate whether this agent may be enhancing performance by inducing generalized fear rather than by specifically facilitating retrieval processes; (4) to obtain information on the relative contribution of peripheral and central CAs to the enhanced retrieval induced by amphetamine.

\section{GENERAL METHODS}

\section{Behavioral Task}

In all of the experiments reported in this investigation, retention was measured by the duration of suppression of drinking following punishment shock administered in the training session. Thirsty mice were trained to drink from a tube and $24 \mathrm{~h}$ later, following an initial period of drinking, were punished each time they touched the spout. Amnesia for the avoidance response was induced by injecting the protein-synthesis inhibitor anisomycin (Ani;
$100 \mathrm{mg} / \mathrm{kg} \mathrm{sc}$ ) immediately following attainment of the learning criterion.

\section{Animals}

The animals used in these experiments were male Swiss-Webster mice obtained from West Jersey Biological Supplies; the mice were approximately 10 weeks old and averaged $35 \mathrm{~g}$ body weight. They were housed two per cage. Food was available ad lib.

\section{Apparatus}

Animals were trained in two identical chambers, the dimensions of which were $10 \mathrm{~cm}$ long $\times 10 \mathrm{~cm}$ wide $\times 6 \mathrm{~cm}$ high. Walls were constructed from black Lucite, and the floor, from aluminum plate. A $10-\mathrm{ml}$ water tube was fixed to the outside of one wall in such a position that the metal spout projected into the center of a 1 -cm-diam hole that was $2 \mathrm{~cm}$ above the floor. Each chamber was housed in a sound-attenuating box. Drinking was detected by a drinkometer circuit, and administration of shock and recording of latencies were accomplished by the use of standard programming equipment. Shock (2.0 mA) was administered from a Lehigh Valley shock generator, the outputs from which were connected to the floor of the chamber and to the metal drinking spout. Noncontingent shock was administered in a gray metal cylinder, $10 \mathrm{~cm}$ in diameter and $15 \mathrm{~cm}$ high. Shock was delivered when the animal touched the walls of the cylinder with the mouth or paws.

\section{General Procedure}

Procedure consisted of three phases: adaptation, training, and testing. Following $24 \mathrm{~h}$ of water deprivation, mice were given an adaptation session in which they explored the chamber and learned the location of the water spout. Animals were removed when they had accumulated a total of $5 \mathrm{sec}$ of contact on the water spout; they were then permitted $1.5 \mathrm{~h}$ of free access to water in the home cage. In the training session $24 \mathrm{~h}$ later, mice were permitted $5 \mathrm{sec}$ of free access to the tube, after which time shock was automatically activated and all subsequent contacts with the tube were punished. The training session was terminated when animals failed to touch the tube in a 60-sec period. Latency to accumulate the initial $5 \mathrm{sec}$ of drinking and the number of shocks before the suppression criterion was attained were recorded for each animal. Animals were given free access to water for $24 \mathrm{~h}$. Retention was tested $48 \mathrm{~h}$ after training by recording the time required to accumulate $5 \mathrm{sec}$ of contact on the water tube. Mice failing to reach the criterion in $1,000 \mathrm{sec}$ were assigned the maximum latency as a test score.

\section{EXPERIMENT 1}

Previous studies from this laboratory that investigated the effects of CA-stimulating agents on amnesias induced by protein-synthesis inhibition have employed a behavioral task in which spontaneous recovery of memory typically occurs $48 \mathrm{~h}$ after training (Quartermain \& Botwinick, 1975b; Quartermain et al., 1977). It is not known whether more durable amnesias induced by protein-synthesis inhibition can likewise be alleviated by pretesting treatment with CA-stimulating agents. The intention of the first experiment was to demonstrate a procedure that results in an amnesia that is durable for at least 7 days. Subsequent experiments determine if d-amphetamine and methylphenidate can alleviate this amnesia. 


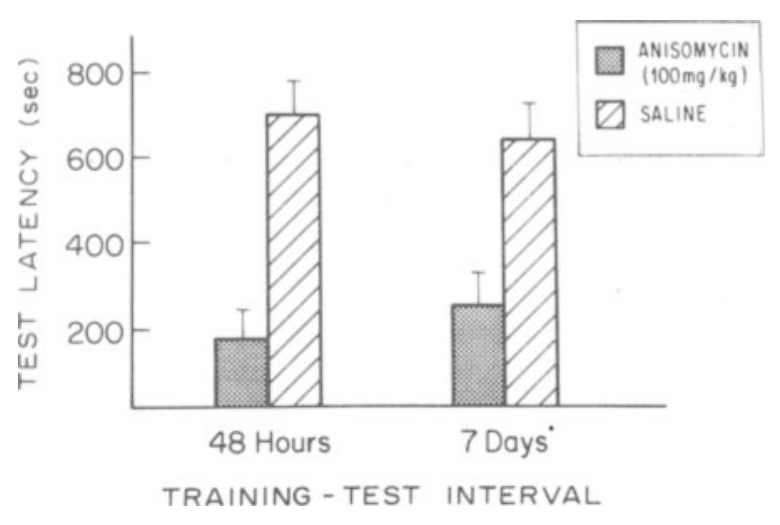

Figure 1. Mean latencies and SEMs for saline- and anisomycintreated mice tested either $\mathbf{4 8} \mathrm{h}$ or $\mathbf{7}$ days after training.

\section{Method}

Fifty-six mice were water deprived and adapted as described in General Methods. On the training day immediately following attainment of the avoidance criterion, they were injected with either saline (Sal) $(\mathrm{N}=20)$ or Ani $(100 \mathrm{gm} / \mathrm{kg} \mathrm{sc})(\mathrm{N}=20)$. Half of each group $(\mathrm{N}=10)$ were tested $48 \mathrm{~h}$ after training, and the other half after 7 days. Water was removed from the home cage $24 \mathrm{~h}$ prior to the retention test.

\section{Results}

The results of this experiment are shown in Figure 1. Latencies for this and all of the following experiments were transformed to logarithims before statistical analysis. Analysis of variance of these data indicate a highly significant difference between drug groups $[F(3,36)=41.6, p \leqslant .001]$ and no significant difference between test intervals $(F=.2)$. These data show that Ani induces a robust amnesia that remains stable for 7 days. Untrained animals tested $48 \mathrm{~h}$ after training typically have latencies between $80-100 \mathrm{sec}$. Comparison of these scores with those of the Ani group suggests that the amnesia is relatively complete. These data indicate that the amnesia produced by Ani in this task is qualitatively different from that employed in our previous studies and should there- fore permit us to determine whether durable amnesias can be ameliorated by pharmacological stimulation of CA systems.

\section{EXPERIMENT 2A: EFFECT OF IMMEDIATE POSTTRAINING AMPHETAMINE ADMINISTRATION}

The objective of this experiment was to determine whether d-amphetamine administered immediately after training would prevent the development of an Ani-induced amnesia. Several studies have shown that posttraining treatment with amphetamine can facilitate memory processing and alleviate amnesias (Flood, Jarvik, Bennett, Orme, \& Rosenzweig, 1977; Krivanek \& McGaugh, 1969; Serota, Roberts, \& Flexner, 1972). Our intention was to attempt to confirm this observation using the amnesia paradigm described in Experiment 1.

\section{Method}

Following adaptation and training, groups of mice were injected with either Sal or different doses of d-amphetamine immediately following treatment with Ani. An additional group of mice were treated with Ani 20 min before training to eliminate the possibility of a reduction in the effectiveness of Ani in inhibiting protein synthesis when the amnestic agent was administered simultaneously with d-amphetamine. The groups and their Ns are shown in Table 1.

\section{Results}

The results shown in Table 1 indicate that amphetamine administered posttraining immediately following Ani clearly failed to block the development of amnesia. This was also true when Ani was given before training and d-amphetamine $(2.0 \mathrm{mg} / \mathrm{kg})$ was administered immediately after. This finding suggests that stimulating the release of CAs during the period immediately after training, when storage and encoding processes are assumed to be active, cannot offset the amnesia induced by inhibition of protein synthesis in the present task. An attempt was also

Mean Latencies and SEMs of Anisomycin-Treated Mice Injected With d-Amphetamine Immediately Following Training

\begin{tabular}{|c|c|c|c|c|c|}
\hline & \multirow[b]{2}{*}{ Group } & \multirow{2}{*}{$\begin{array}{c}\text { Amphetamine } \\
\text { Dose* }\end{array}$} & \multirow[b]{2}{*}{$\mathrm{N}$} & \multicolumn{2}{|c|}{ Latency } \\
\hline & & & & Mean & SEM \\
\hline 1 & Anisomycin/d-Amphetamine & .0 & 10 & 139.2 & 33.3 \\
\hline 2 & Anisomycin/d-Amphetamine & 1.0 & 10 & 196.7 & 73.3 \\
\hline 3 & Anisomycin/d-Amphetamine & 2.0 & 10 & 180.7 & 51.6 \\
\hline 4 & Anisomycin $(20$ min pretraining $) / \mathrm{d}$-Amphetamine & .0 & 9 & 196.1 & 81.8 \\
\hline 5 & Anisomycin $(20 \mathrm{~min}$ pret raining $) / \mathrm{d}-$ Amphetamine & 2.0 & 10 & 300.1 & 106.5 \\
\hline 6 & d-Amphetamine (20 min pretraining)/Anisomycin (immediately post training) & 2.0 & 10 & 55.8 & 30.6 \\
\hline 7 & Saline/Saline & & 10 & 563.7 & 155.9 \\
\hline
\end{tabular}

*In milligrams per kilogram. 
made to block the amnesic effect of Ani by treating mice with amphetamine $(2.0 \mathrm{mg} / \mathrm{kg}) 20 \mathrm{~min}$ before Ani was administered. These mice showed normal approach latencies, and the number of shocks required to reach the training criterion was not different from the numbers for the mice trained with the regular procedure. However, as can be seen from Table 1, these animals (Group 6) had significantly shorter latencies $(t=3.3, p<.01)$ than those in the group treated only with Ani (Group 1). This may indicate that release of CAs prior to the administration of Ani exacerbates the amnesia, perhaps because of the reduction in levels of CAs consequent on their release from storage. The results of this experiment are clear; in this task, amnesia induced by Ani cannot be ameliorated by immediate posttraining administration of amphetamine.

\section{EXPERIMENT 2B: EFFECTS OF AMPHETAMINE ADMINISTERED BEFORE TESTING}

In a previous experiment, we showed that pretest administration of d-amphetamine reversed an amnesia for a spatial discrimination habit induced by the protein-synthesis inhibitor cycloheximide (CXM). On the other hand, Quinton \& Bloom (1977) failed to demonstrate alleviation of CXM-induced amnesia for a step-through avoidance response when d-amphetamine was administered prior to testing, although immediate posttraining treatment was effective. The intention of this experiment was to test the generality of our previous finding by determining whether pretest amphetamine administration would reverse an amnesia induced for an inhibitory avoidance response by Ani.

\section{Method}

Mice were adapted and trained as previously described. Immediately following training, one group of animals $(\mathrm{N}=14)$ were injected with Sal and the remainder $(N=54)$ with Ani. Thirty minutes prior to testing $48 \mathrm{~h}$ later, the Sal group were again injected with Sal and the Ani-treated mice were injected with either .0 (Sal, $\mathrm{N}=14), .1, .5,1.0$, or $2.0 \mathrm{mg} / \mathrm{kg}$ d-amphetamine ip ( $N=10$ per group).

\section{Results}

In contrast with the effects of posttraining administration, treatment with d-amphetamine prior to testing produced substantial and significant attenuation of the Ani amnesia. Figure 2 shows mean latency plotted against log dose of amphetamine. An analysis of variance of the transformed latencies shows a significant difference in test latency among treatment groups $[F(4,49)=9.98, p<.01]$. Subsequent comparisons of drug groups with the Ani-Sal control indicated that amphetamine at $.1 \mathrm{mg} / \mathrm{kg}$ did not

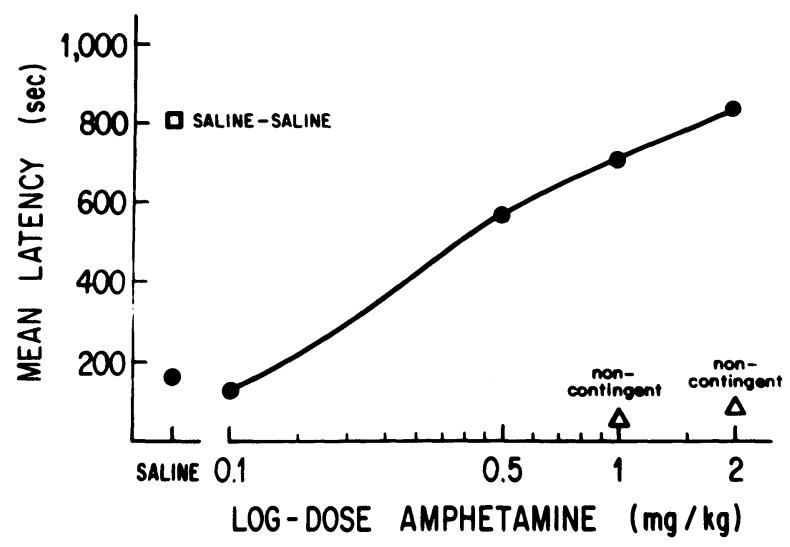

Figure 2. Test scores of anisomycin-treated mice injected with saline or different doses of d-amphetamine $30 \mathrm{~min}$ before the retention test. The two noncontingent groups received anisomycin following punishment shock in a different apparatus on the training day. These animals were injected with either 1 or $2 \mathrm{mg} / \mathrm{kg}$ d-amphetamine $\mathbf{3 0} \mathrm{min}$ prior to testing in the regular training apparatus.

produce significant alleviation of the amnesia $(t=.6)$ but that at $.5 \mathrm{mg} / \mathrm{kg}(\mathrm{t}=2.5, \mathrm{p}<.05), 1.0 \mathrm{mg} / \mathrm{kg}$ $(\mathrm{t}=3.7, \mathrm{p}<.01)$, and $2.0 \mathrm{mg} / \mathrm{kg}(\mathrm{t}=5.5, \mathrm{p}<.001)$, the Ani amnesia was significantly reduced. A probit analysis (Finney, 1971) calculated from the transformed scores of Figure 1 indicated that the $E D_{s 0}$ for d-amphetamine in this task is $1.17 \mathrm{mg} / \mathrm{kg}$.

These results confirm and extend our previous findings (Quartermain \& Botwinick, 1975b) and indicate that amnesias induced for both multiple-trial appetitively motivated discrimination learning and inhibitory avoidance responding can be ameliorated by treatment with d-amphetamine prior to testing. Reasons for the discrepancy between the present findings and those reported by Quinton \& Bloom (1977) are not readily apparent. The different inhibitory avoidance tasks employed in the two studies (step through and drink suppression) cannot be responsible for the different results, since we have shown (Experiment 3) that an amnesia for a stepthrough passive-avoidance task produced by Ani can also be attenuated by amphetamine administered before the retention test. It is possible that the different results may be due to the different mouse strains employed in the two studies. Quinton \& Bloom (1977) used the inbred C57BL6 strain, whereas randomly bred Swiss-Webster mice were employed in the present experiment.

\section{EXPERIMENTS 3A AND 3B: CONTROLS FOR NONSPECIFIC EFFECTS OF D-AMPHETAMINE}

In order to demonstrate that pretest administration of amphetamine facilitates retrieval, it is necessary to show that the enhanced performance is not the result of some side effect of the drug that produces be- 
havioral changes that are misinterpreted as improved retention. In our previous study (Quartermain \& Botwinick, 1975b) we evaluated the specificity of the amphetamine enhancement of retention by employing a reversal procedure. Our results showed that amnestic animals treated with amphetamine had significantly better retention performance than amnestic animals treated with Sal on a conventional relearning test but showed significantly poorer performance if a reversal measure was used to index retention. This pattern of results suggests that amphetamine enhances the retrieval of the spatial discrimination, rather than nonspecifically facilitating performance. In the present experimental procedure, in which enhanced retention is indexed by increased latencies to perform the learned response, it is necessary to evaluate the possible contribution of nonspecific effects of acute amphetamine treatment which might inhibit ongoing behavior. This can be most readily accomplished by use of noncontingent training procedures in which animals are treated identically to the experimental mice except that they are given training in a different apparatus. Two variations of this procedure are described in the following experiments.

\section{Experiment 3A}

\section{Method}

A group of 42 mice were adapted to the drinking chamber as previously described. On Day 2 , one group $(\mathrm{N}=14)$ was given the standard training procedure followed by the injection of Ani. The remaining 28 mice were given noncontingent training instead of the avoidance conditioning. This was accomplished by placing each mouse in the noncontingent shock apparatus described in General Methods and administering three 2.0-mA shocks when animals touched the walls of the cylinder with the paws or the nose. Ani was injected immediately after. Forty-eight hours later, all mice were tested in the regular training apparatus. Thirty minutes prior to the test, the 14 regularly trained mice and 14 of the noncontingently trained animals were injected with $2.0 \mathrm{mg} / \mathrm{kg}$ of amphetamine. The remaining 14 animals were treated with Sal.

\section{Results}

These results are shown in Table 2. Contingently trained mice showed the expected increase in latency to drink, a fact that confirms the results of Experiment 2B. In contrast, noncontingently trained mice did not increase latencies to drink following $d$ amphetamine treatment. Test latency scores of this group were significantly shorter than those of contingently trained animals $(t=5.8, p<.001)$ and not

Table 2

Test Latencies of Mice in Experiment 3A

\begin{tabular}{lccr}
\hline \multicolumn{1}{c}{ Group } & $\mathrm{N}$ & Mean & SEM \\
\hline Contingent Amphetamine & 14 & 887.9 & 107.2 \\
Noncontingent Amphetamine & 14 & 148.4 & 67.5 \\
Noncontingent Saline & 14 & 103.4 & 31.1 \\
\hline
\end{tabular}

reliably different from the scores of noncontingently trained mice treated with Sal before testing $(t=.6)$. These findings demonstrate that d-amphetamine increases latencies to drink only in animals that have been given specific avoidance training. This result is consistent with the hypothesis that d-amphetamine facilitates retrieval of stored memories.

\section{Experiment 3B}

In this experiment, we attempted to confirm this conclusion by determining whether the memoryenhancing effects of amphetamine were specific to different avoidance responses learned in different environments. In this experiment, mice were trained on either a standard step-through passive-avoidance task or in the drink-suppression task previously described. Amnesia for both tasks was induced by Ani, and amphetamine was injected prior to the retention test. Animals from each training condition were then tested an either the task on which they were trained or on the alternate task. On the basis of the results of Experiment $3 \mathrm{~A}$, it would be predicted that amphetamine would only increase latencies of mice tested in the apparatus in which they had been trained.

\section{Method}

Apparatus. The apparatus for the drink-suppression task was the same as previously described. Step-through passive-avoidance training was carried out in a standard LVE mouse shuttlebox $9 \mathrm{~cm}$ wide $\times 11 \mathrm{~cm}$ high $\times 23 \mathrm{~cm}$ long, divided into two equal sections by a wall that contained a 4 -cm-square opening in the center that could be blocked by a vertically sliding door. The acrylic walls of one side of the apparatus were white and the lid was clear acrylic; on the other side, the wall and lid were black. The floor was made of stainless steel rods $(.3 \mathrm{~cm}$ in diameter, $7 \mathrm{~cm}$ between rods). Electromechanical circuitry was used to record responses and latencies and to activate a Coulbourn Instruments solid-state shocker-distributor that was connected to the floor bars of the black side.

Procedure. Forty mice were trained in the step-through task according to the following procedure. Mice were placed in the white compartment, and after $5 \mathrm{sec}$, the door was raised to allow access to the black shock compartment. When the animal crossed into the black side, a .4-mA shock was automatically delivered to the bars. Animals were permitted to escape shock by running back to the white compartment. Latency to first cross and number of shocks received until the criterion of no entries in a $60-\mathrm{sec}$ period were recorded for each mouse. Immediately following training, mice were injected with Sal $(\mathrm{N}=10)$ or Ani $(\mathrm{N}=30)$. Thirty mice were trained in the drink-suppression task using the procedure previously described. Immediately after training, all mice were injected with Ani. Testing was carried out $48 \mathrm{~h}$ later. Animals were treated with either Sal or d-amphetamine $(2 \mathrm{mg} / \mathrm{kg})$ and tested on either the step-through or drink-suppression task, as indicated in Table 3.

\section{Results}

Table 3 shows the results of this experiment. The difference in test latencies between Groups 1 and 2 provides evidence for the amnestic effects of Ani in this version of the step-through paradigm $(t=4.9$, 
Table 3

Test Latencies for Mice Trained and Tested in Step Through (ST) and Drink Suppression (DS) Avoidance Tasks

\begin{tabular}{|c|c|c|c|c|c|c|}
\hline \multicolumn{3}{|c|}{ Training } & \multicolumn{4}{|c|}{ Testing } \\
\hline Group & Task & $\begin{array}{c}\text { Drug } \\
\text { (immediately posttraining) }\end{array}$ & $\begin{array}{c}\text { Drug } \\
\text { (30 min pretest) }\end{array}$ & Task & $\begin{array}{c}\text { Mean } \\
\text { Latency }\end{array}$ & $\begin{array}{l}\text { Mean Percent } \\
\text { Latency* }\end{array}$ \\
\hline 1 & ST & Saline & Saline & ST & 271.2 & 90.4 \\
\hline 2 & ST & Anisomycin & Saline & ST & 80.7 & 26.9 \\
\hline 3 & ST & Anisomycin & d-Amphetamine & ST & 204.3 & 68.1 \\
\hline 4 & ST & Anisomycin & d-Amphetamine & DS & 149.0 & 14.9 \\
\hline 5 & DS & Anisomycin & Saline & DS & 179.0 & 17.9 \\
\hline 6 & DS & Anisomycin & d-Amphetamine & DS & 888.0 & 88.8 \\
\hline 7 & DS & Anisomycin & d-Amphetamine & ST & 42.3 & 14.1 \\
\hline
\end{tabular}

Note-Anisomycin was given subcutaneously at $100 \mathrm{mg} / \mathrm{kg}$; d-amphetamine was given intraperitoneally at $2.0 \mathrm{mg} / \mathrm{kg}$. $\mathrm{N}=10 / \mathrm{group}$. *Percent of maximum 300 for $S T, 1,000$ for DS.

$p \leqslant .001$ ). The results of Group 3 indicate that pretest amphetamine treatment can reverse the amnestic effects of Ani in this task (Group 2 vs. Group 3: $\mathrm{t}=2.45, \mathrm{p} \leqslant .05$ ). This finding fails to confirm Quinton \& Bloom's (1977) observation that amnesia induced by protein-synthesis inhibition cannot be alleviated by pretest amphetamine injection. That this effect of amphetamine is specific to animals with memory of step-through passive-avoidance training is indicated by the results of Group 4. These animals were deprived of water and adapted to the DS apparatus $24 \mathrm{~h}$ prior to the ST training. The following day they received ST training followed by administration of Ani. Forty-eight hours later, these mice were injected with amphetamine and tested while thirsty in the DS chamber. The results show that amphetamine failed to significantly elevate drink latencies under these conditions. In an informal test, these mice were returned to the ST apparatus and latency to cross into the dai $\mathbf{k}$ side was recorded. Mean latency was $271.9 \mathrm{sec}$, which was similar to the scores of animals in Group 3 that were trained and tested in the ST apparatus. Groups 5 and 6 showed the results of the reverse procedure. Group 6 was tested in the drink chamber following amphetamine injection and showed the expected increase in latency relative to Sal animals $(t=3.74, p<.002)$. Mice in Group 7 were tested in the ST task following amphetamine treatment. No increase in response latencies is evident in this group. These two experiments clearly show that amphetamine fails to induce avoidance behavior in untrained animals, a fact that eliminates nonspecific side effects as a cause of increased latencies in drug-treated mice.

\section{EXPERIMENT 4: EFFECTS OF FEAR AND STRESS-INDUCING TREATMENTS ON ANISOMYCIN-INDUCED AMNESIA}

Although the results of Experiment 3 are consistent with the hypothesis that d-amphetamine enhances retrieval processes, an alternative explanation for these findings is possible. It might be supposed that d-amphetamine has fear-enhancing properties that summate with the residual memory to produce an above-threshold avoidance response. According to this interpretation, the effect of amphetamine would be attributed to additional learning rather than to facilitated retrieval. As one test of this hypothesis, we investigated the effects of substituting, for amphetamine, treatments that are presumed to induce fear and arousal. One treatment consisted of injecting a dose of pentylenetetrazol (PTZ), a CNS stimulant, which has been shown to have anxiogenic properties (Sherman \& Lal, 1979). Another treatment consisted of administering a noncontingent footshock in a neutral apparatus, a procedure that has been shown to act as a reminder in step-through passive-avoidance studies (Quartermain, McEwen, \& Azmitia, 1972). A third treatment consisted of an injection of a dose of strychnine sulfate $(.5 \mathrm{mg} / \mathrm{kg})$, which substantially enhances general arousal in Swiss-Webster mice. This group was included to determine if nonspecific arousal would be sufficient to alleviate the amnesia. These groups were compared with a group given $2.0 \mathrm{mg} / \mathrm{kg}$ of d-amphetamine. A final group were Ani-Sal controls. All of these treatments were administered $30 \mathrm{~min}$ prior to testing to animals made amnestic by a posttraining injection of Ani.

\section{Results}

Table 4 shows the test latencies of these groups. Amphetamine $(2.0 \mathrm{mg} / \mathrm{kg})$ significantly enhanced test latencies relative to Ani-Sal controls $(t=3.14$, $p \leqslant .005)$, thus confirming the results of Experiment 2B. However, none of the other treatments alleviated the amnesia. The dose of PTZ has been reported to have fear-inducing properties in rats and is the highest that can be safely administered to mice without inducing convulsions. Informal experiments with PTZ at $10.0 \mathrm{mg} / \mathrm{kg}$ also produced negative results. It is notable that moderately severe footshock also failed to induce suppression of drinking. Although mice were noticeably stressed $\mathbf{3 0}$ min after the three shocks, test scores were not significantly different from those of the amnestic control group. The 
Table 4

Effect of Fear- and Stress-Inducing Treatments on Anisomycin-Induced Amnesia

\begin{tabular}{lrrrr}
\hline & & & \multicolumn{2}{c}{ Latency } \\
\cline { 4 - 5 } & & Group & Mean & SEM \\
\hline 1 & Anisomycin/Saline & 10 & 328.1 & 86.5 \\
2 & Anisomycin/d-Amphetamine & 9 & 764.0 & 110.5 \\
3 & Anisomycin/Footshock & 9 & 245.2 & 98.6 \\
4 & Anisomycin/Pentylenetetrazol & 10 & 400.0 & 98.8 \\
5 & Anisomycin/Strychnine & 10 & 354.2 & 106.1 \\
\hline
\end{tabular}

Note-Group 1 vs. $2 t=3.14, p \leqslant .004$. Dosages: anisomycin, $100 \mathrm{mg} / \mathrm{kg}$; d-amphetamine, $2.0 \mathrm{mg} / \mathrm{kg}$; footshock, three 2-mA shocks in neutral apparatus; pentylenetetrazol, $.20 \mathrm{mg} / \mathrm{kg}$; strychnine, $.5 \mathrm{mg} / \mathrm{kg}$.

failure of this treatment to alleviate the amnesia resulted because, perhaps, the attributes aroused by footshock did not correspond closely enough to the stored representation of the drink-shock contingency. Reminder treatments may have to be quite specific in order to facilitate retrieval processes.

We have recently shown that doses of epinephrine that mimic some of the hormonal consequences of shock-induced stress fail to alleviate an amnesia for a step-through inhibitory avoidance response (Judge \& Quartermain, 1982). Taken together, these findings indicate that pharmacologically and behaviorally induced arousal and stress are not by themselves sufficient to alleviate forgetting induced by inhibition of protein synthesis. This conclusion is supported by additional, unpublished data collected in this laboratory, which showed that neither the adrenergic agonists clonidine or isoproterenol administered peripherally nor norepinephrine or clonidine administered intracerebroventricularly (Altman \& Quartermain, 1982) alleviated amnesia induced by Ani in the drink suppression paradigm.

\section{EXPERIMENT 5: EFFECTS OF METHYLPHENIDATE}

The purpose of this study was to obtain further evidence that release of CAs prior to testing facilitates retrieval processes by determining if the amnesia induced by Ani can be alleviated by methylphenidate. Methylphenidate is a structural analog of amphetamine, but, unlike the parent compound, which preferentially releases newly synthesized (free) CAs, it releases CAs from reserpine-sensitive storage pools (Moore, 1978). Positive findings with this agent would provide additional support for CA involvement in memory-retrieval processes.

\section{Method}

Animals were adapted and trained according to the procedures described in Experiment 2B. Immediately following training, 10 mice were injected with Sal and $\mathbf{4 0}$ with Ani. Thirty minutes prior to testing, the Sal mice were given a second injection of Sal and the
Ani-treated mice were injected with either 0 (Sal), 2, 15, or $20 \mathrm{mg} / \mathrm{kg}$ methylphenidate ( $\mathrm{N}=10$ per group).

\section{Results and Discussion}

Figure 3 shows the results of this experiment. Analysis of variance of the transformed latencies indicated a significant difference among the methylphenidate-treament group $[F(3,36)=5.8, p<.01]$. Comparisons of the individual dose groups with the Ani-Sal $(0-\mathrm{mg} / \mathrm{kg})$ control group showed that the amnesia was not reversed by the 2.0 -mg dose but that both the $15-\mathrm{mg} / \mathrm{kg}(\mathrm{t}=3.1, \mathrm{p} \leqslant .01)$ and the 20 $\mathrm{mg} / \mathrm{kg}$ dose $(\mathrm{t}=3.8, \mathrm{p}<.01)$ significantly reduced the amnestic effects of Ani. The data in Figure 3 were transformed to percent latencies, and the $\mathrm{ED}_{\mathbf{3 0}}$ was computed using the procedure of Finney (1971). The results of this calculation revealed that the $\mathrm{ED}_{\mathbf{s o}}$ was $3.82 \mathrm{mg} / \mathrm{kg}$. Although the effective doses of methylphenidate were higher than those of d-amphetamine, the behavioral effects were qualitatively similar. No evidence of stereotopies was observed, and locomotor activity appeared normal. All mice who did not drink at the test did so immediately after being returned to the home cage. These findings indicate that CAs released from storage sites enhance retention in a manner comparable to that observed when newly synthesized CAs are released by amphetamine. The results of this experiment provide further support for a role for the CAs in memory-retrieval processes.

\section{EXPERIMENT 6: EFFECT OF RELEASING PERIPHERAL CAs WITH 4-HYDROXYAMPHETAMINE}

The chemical 4-hydroxyamphetamine (4-OHA) is a structural analog of amphetamine that has difficulty in penetrating the brain from the peripheral circulation. It is therefore a useful pharmacological tool with which to evaluate the relative contributions of central and peripheral CAs to memory processes. Recent findings have indicated that peripheral CAs

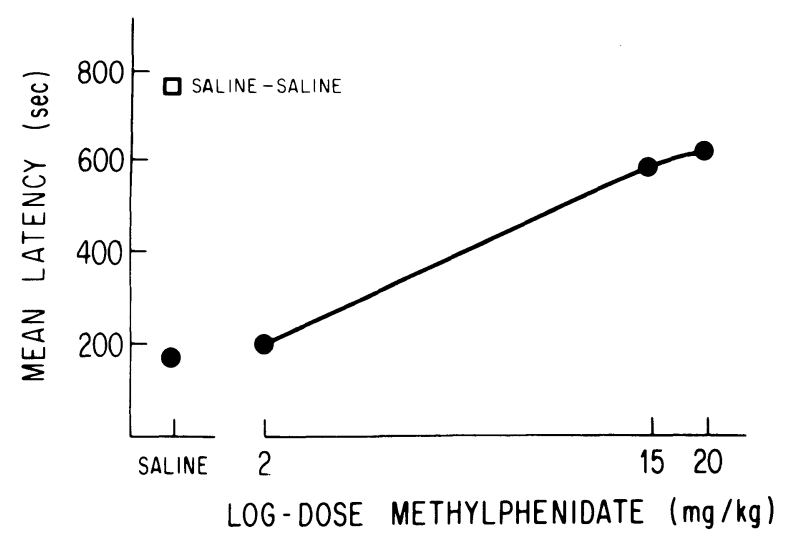

Figure 3. Test latencies for anisomycin-treated mice injected with saline or different doses of methylphenidate $\mathbf{3 0}$ min prior to the retention test. 
play an important role in mediating the memoryenhancing effects of CA agents administered before (Sternberg \& Gold, 1981) and immediately after (Martinez, Vasquez, Jensen, Messing, Rigter, Liang, and McGaugh, 1979) training. The intention of the present experiment was to determine the role of peripheral CAs in retrieval processes by administering various doses of 4-OHA along with the standard d-amphetamine dose, $30 \mathrm{~min}$ prior to the retention test.

\section{Method}

Animals were adapted and trained as previously described. Immediately following training, 14 mice were injected with Sal and 50 with Ani. Thirty minutes prior to the retention test, the $14 \mathrm{Sal}$ mice were given a second Sal injection and the Ani-treated mice were given Sal, d-amphetamine $(2 \mathrm{mg} / \mathrm{kg})$, or $2.0,1.0$, or $.5 \mathrm{mg} / \mathrm{kg}$ of 4-OHA. Each group comprised 10 mice.

\section{Results and Discussion}

Table 5 shows the results of this experiment. The Sal-Sal control group (Group 1) shows the typical retention performance of untreated animals in this task, while Group 2 shows the expected amnesia. The scores of the d-amphetamine reference group are similar to those of Experiment $2 \mathrm{~B}$ and confirm those findings. In contrast with d-amphetamine, 4OHA failed to increase test latencies at any of the doses employed. The amnesia induced by Ani was somewhat more robust than in the other experiments, but d-amphetamine was still able to produce substantial memory recovery. These findings suggest that retrieval performance, in contrast with encoding and storage, may be more dependent on central than on peripheral CAs.

\section{GENERAL DISCUSSION}

The principal result of this study is that treatment with the CA stimulant d-amphetamine prior to retention testing results in alleviation of an amnesia induced by Ani. This conclusion is strengthened by the results of the control experiments, which showed that

Table 5

Effect of 4-Hydroxyamphetamine on Anisomycin-Induced Amnesia

\begin{tabular}{llrc}
\hline & \multicolumn{2}{c}{ Group } & \multicolumn{2}{c}{ Test Latency } \\
\cline { 3 - 4 } & & Mean & SEM \\
\hline 1 & Saline/Saline & 790.0 & 116.97 \\
2 & Anisomycin/Saline & 88.7 & $30.99^{*}$ \\
3 & Anisomycin/d-Amphetamine (2.0) & 696.0 & $126.9 * *$ \\
4 & Anisomycin/4-Hydroxyamphetamine (2.0) & 69.0 & 17.5 \\
5 & Anisomycin/4-Hydroxyamphetamine (1.0) & 113.6 & 72.8 \\
6 & Anisomycin/4-Hydroxyamphetamine (.5) & 99.1 & 31.2 \\
\hline
\end{tabular}

Note-Group 1, $N=14$; Groups 2-6, $N=10$.

*Significantly different from Group $1(t=4.95, p \leqslant .0001)$.

**Significantly different from Group $2(t=4.65, p \leqslant .0002)$. the increased latencies to respond cannot be attributed to any nonspecific effect of acute amphetamine treatment; d-amphetamine suppressed responding only in situations in which the animals had previously received specific avoidance training. These results also cannot be easily accounted for by assuming that amphetamine induces generalized fear and thus adds new learning to a weakened memory trace. The results of Experiment 4 and other work from this laboratory suggest that this hypothesis is unlikely to be correct. We believe that the pattern of results from this study is consistent with the notion that amphetamine facilitates retrieval of stored memories.

This study did not attempt to determine whether or not d-amphetamine would enhance performance in nonamnestic animals. We expect that it does so, since saline-treated mice frequently do not show maximum retention. Our view of the role of amphetamine in retrieval predicts that this agent improves performance in all circumstances in which memory is less than complete. When animals have strong memory, however, amphetamine should have no effect on performance. We (Quartermain \& Judge, Note 1) have recently shown, using an activeavoidance test procedure, that forgetting of Pavlovian fear conditioning induced by both Ani and a 28-day retention interval could be alleviated by pretesting treatment with d-amphetamine $(2.0 \mathrm{mg} / \mathrm{kg})$. Control animals who had strong memory $24 \mathrm{~h}$ after training did not show improved performance when treated with amphetamine, even though it was physically possible for them to do so.

An effect of amphetamine on retrieval processes has also been suggested by Wise and Stein (1970), who propose that amphetamine facilitates goaldirected behavior maintained by both reward and the avoidance of punishment. They suggest that amphetamine is not involved in instigating new behaviors; rather, they believe the drug acts by lowering the activation threshold for old, previously stored memories. Wise and Stein claim that this facilitation of old behavior is a function of amphetamine that is distinct from its central stimulating actions. Such a distinction is also consistent with the present results. In these experiments, amphetamine suppressed responding at a dose level $(2.0 \mathrm{mg} / \mathrm{kg})$ that normally enhances general activity. It remains to be determined whether the neurochemical correlates of amphetamine-induced facilitation of retrieval are different from those that mediate its effects on general arousal.

The failure of amphetamine to enhance retention when it is administered immediately posttraining is somewhat surprising, especially since other studies have reported positive effects. It remains possible that differences in task variables may play an important role, since most of the positive findings have been obtained in studies in which amnesia has been 
induced for step-through inhibitory avoidance.

The results of Experiment 6 showed that the amnesia was not alleviated when 4-OHA was administered prior to testing. This suggests that peripheral CAs may play a less significant role in facilitating retrieval than in modulating storage processes. The suggestion that central CAs are of primary importance in activating the retrieval mechanism is consistent with previous work from this laboratory. First, we have shown that the reversal of amnesia induced by pretest treatment with the monoamine oxidase (MAO) inhibitor pheniprazine can be blocked by pretreatment with reserpine but not with syrosingopine, which preferentially depletes peripheral CAs (Quartermain \& Botwinick, 1975b). Second, we have recently shown that centrally administered d-amphetamine can alleviate anisomycin-induced amnesia. Taken together with the present result, these findings suggest that retrieval processes may be more dependent on the release of central than of peripheral CAs.

These experiments do not provide any information on the mechanisms by which amphetamine treatment facilitates memory retrieval. Many different mechanisms of action have been proposed for amphetamines, including direct stimulation of CA receptors (Smith, 1963), inhibition of MAO (Mann \& Quastel, 1940), release of CAs (Moore, Carr, \& Dominic, 1970), and blockade of reuptake of released CAs (Glowinski \& Axelrod, 1965). Any of these mechanisms may underlie the effects of amphetamine reported in this study. The present experiment is also uninformative regarding the specific CA that might mediate the effects on retrieval processes. Both NE and DA have been implicated in amphetamine's effects on behavior (Moore, 1978). Preliminary findings from our laboratory suggest that DA may be mediating the behavioral effects of amphetamine in these studies. Our results show that pretreatment with AMPT (which inhibits synthesis of both NE and DA) blocks amphetamine-induced retrieval enhancement but that pretreatment with DEDTC or FLA-63 (agents that inhibit NE biosynthesis at the dopamine beta hydroxylase step) are ineffective. In addition, the effects of amphetamine on anisomycin-induced amnesia can be mimicked by the DA agonists apomorphine, lisuride, and pergolide.

At the conceptual level, the findings of this study add to the accumulating evidence that treatment with protein-synthesis inhibitors can disrupt memory-retrieval mechanisms (Barraco \& Stettner, 1976; Quartermain, 1976; Quartermain, 1981b; Rainbow, 1982). Spear (1978) has outlined a conceptual framework that would permit the results of amnesia experiments to be integrated with the findings from both human and animal studies of memory retrieval. According to this formulation, retrieval failure occurs whenever the stimulus conditions at testing (retrieval) diverge substantially from those that were present during acquisition (storage). Central to this stimulus-similarity principle is the notion that what is stored in memory is a multidimensional collection of attributes consisting of representations of the nominal CS and UCS as well as of the contextual cues (both internal and external) within which the target event is embedded. Retrieval of this event occurs if a sufficient number of the attributes of the memory are present in the test environment. According to this notion, amnestic treatments disrupt retention because they interfere with the stimulus-processing operations that establish associative connections between the occurrence of the UCS and the environmental context. The contextual stimuli are an important source of retrieval cues for obtaining access to the target memory at testing; if they are poorly or weakly encoded with the target memory, they will be unavailable to assist retrieval, and retention loss will ensue. This view of the action of amnestic agents, which has been appearing with increasing frequency in the animal memory literature (Lewis, 1979; Mactutus et al., 1980; Spear, 1978), has its antecedents in the literature of human memory retrieval. For example, in outlining the encodingspecificity principle of human memory retrieval Tulving and Thomson (1973) state, "Specific encoding operations performed on what is perceived determines what is stored and what is stored determines what retrieval cues are effective in providing access to what is stored" (p. 353). These converging views of memory-retrieval processes are providing the basis for a much-needed theoretical integration of human and animal research findings on memory loss.

The view of memory processing outlined above predicts that many amnesias can be reversed by making the retrieval environment more similar to that existing during storage. The results of studies in which pretest cuing and treatment with adrenergic stimulants and hormones have been shown to alleviate experimentally induced amnesias are consistent with this view of retrieval failure (Lewis, 1979; Quartermain et al., 1972; Sara \& Remacle, 1977). It is within this context that the effects of amphetamine treatment in the present experiments can be most readily understood. Although the specific neurobiological mechanisms that mediate the amphetamineinduced triggering of retrieval cannot be specified at this time, several general hypotheses can be proposed. For example, amphetamine may reinstate significant internal cues associated with original learning and thereby establish sufficient continuity with the training situation to produce retrieval of the avoidance response. Another possibility is that amphetamine may facilitate processes associated with selective attention so that stimuli associated with training can be more readily recognized in the retrieval environment. A more general possibility is that amphetamine may influence the processes rather than the effectiveness of retrieval by priming 
the CNS, the result being that the threshold of accessibility for all memories is lowered nonspecifically. The evaluation of these hypotheses is one of the goals of our current work.

\section{REFERENCE NOTE}

1. Quartermain, D., \& Judge, M. E. Amphetamine alleviates forgetting of fear conditioning following a long retention interval. Manuscript in preparation, 1982.

\section{REFERENCES}

Altman, H. J., \& Quartermain, D. Facilitation of memory retrieval by centrally administered catecholamine stimulating agents. Behavioral Brain Research, 1982, in press.

Barraco, R. S., \& Stettiner, L. J. Antibiotics and memory. Psychological Bulletin, 1976, 82, 242-302.

Deweer, B., Sara, S. J., \& Hars, B. Contextual cues and memory retrieval in rats: Alleviation of forgetting by pretest exposure to background stimuli. Animal Learning \& Behavior, $1980,8,265-272$.

Finney, D. J. Probit analysis. Cambridge: University Press, 1971.

Flood, J. L., Jarvik, M. E., Bennett, E. L., Orme, A. E., \& Rosenzweig, M. R. The effect of stimulants, depressants and protein synthesis inhibition on retention. Behavioral Biology, 1977, 20, 168-183.

Freedman, L. S., Bachman, M. Z., \& Quartermain, D. Clonidine reverses the amnesia induced by dopamine beta hydroxylase inhibition. Pharmacology, Biochemistry and Behavior, 1979, 11, 259-263.

Glowinski, J., \& Axelnod, J. Effects of drugs on the uptake, release and metabolism of ${ }^{3} \mathrm{H}$ norepinephrine in the rat brain. Journal of Pharmacology and Experimental Therapeutics, 1965, 149, 43-49.

Gordon, W. C. Mechanisms of cue-induced retention enhancement. In N. E. Spear \& R. R. Miller (Eds.), Information processing in animals: Memory mechanisms. Hillsdale, N.J: Erlbaum, 1981.

Hamburg, M. D., \& Cohen, R. P. Memory access pathways: Role of adrenergic versus cholinergic neurons. Pharmacology, Biochemistry and Behavior, 1973, 1, 279-300.

Judge, M. E., \& Quartermain, D. Alleviation of anisomycininduced amnesia by pre-test treatment with lysine-vasopressin. Pharmacology, Biochemistry and Behavior, 1982, 16, 463-466.

KRIVANEK, J., \& McGAUGH, J. L. Facilitating effects of pre and post trial amphetamine administration on discrimination learning in mice. Agents and Actions, 1969, 1, 12-16.

Kurtz, P., \& Palfai, T. Effects of reserpine on retention of escape reversal in mice: Absence of state dependent learning. Journal of Comparative Physiological Psychology, 1978, 9, 393-406.

LEWIS, D. J. Psychobiology of active and inactive memory. Psychological Bulletin, 1979, 86, 1054-1083.

Mactutus, C. F., McCutcheon, K., \& Riccio, D. C. Body temperature cues as contextual stimuli: Modulation of hypothermia-induced retrograde amnesia. Physiology \& Behavior, 1980, 25, 875-883.

ManN, P. J. G., \& QuAstel, J. H. Benzedrine and brain metabolism. Biochemistry Journal, 1940, 34, 414-431.

Martinez, J. L., Vasquez, B., Jensen, R., Messing, R., Rigter, H., Liang, K., \& McGaugh, J. Adrenal medullary catecholamines are necessary for amphetamine-induced enhancement of learning in rats. Neuroscience Abstracts, 1979, 5, 320.

Moore, K. E. Amphetamines: Biochemical and behavioral actions in animals. In L. L. Iverson \& S. H. Snyder (Eds.), Handbook of psychopharmacology (Vol. 2): Stimulants. New York: Plenum Press, 1978.

Moore, K. E., CARr, C. L., \& Dominic, J. A. Functional significance of brain catecholamines. In E. Costa \& S. Garattini
(Eds.), Amphetamines and related compounds. New York: Raven Press, 1970.

QuARTE RMAin, D. The influence of drugs on learning and memory. In M. R. Rosenzweig \& E. L. Bennett (Eds.), Neural mechanisms of learning and memory. Cambridge, Mass: M.I.T. Press, 1976.

Quartermain, D. Catecholamine involvement in memory retrieval processes. In A. R. Morrison \& P. L. Strick (Eds.), Changing concepts of the nervous system. New York: Academic Press, 1982. (a)

Quartermain, D. The role of catecholamines in memory processing. In J. A. Deutsch (Ed.), The physiological basis of memory (2nd ed.). New York: Wiley, 1982. (b)

Quartermain, D., \& Botwinick, C. Y. Effect of age of habit on susceptibility to cycloheximide-induced amnesia in mice. Journal of Comparative and Physiological Psychology, 1975, 89, 803-809. (a)

Quartermain, D., \& Botwinick, C. Y. Role of the biogenic amines in the reversal of cycloheximide-induced amnesia. Journal of Comparative and Physiological Psychology, 1975, 88, 306-401. (b)

Quartermain, D., Freedman, L. S., Botwinick, C. Y., \& Gutwein, B. M. Reversal of cycloheximide-induced amnesia by adrenergic receptor stimulation. Pharmacology, Biochemistry and Behavior, 1977, 7, 259-267.

Quartermain, D., McEwen, B. S., \& Azmitia, E. C. Recovery of memory following amnesia in the rat and mouse. Journal of Comparative and Physiological Psychology, 1972, 79, 360-370.

Quinton, E. E., \& BLоOM, A. S. Effects of d-amphetamine and strychnine on cycloheximide diethyldithiocarbamate-induced amnesia in mice. Journal of Comparative and Physiological Psychology, 1977, 91, 1390-1397.

RaInbow, T. C. Amnestic effect of protein synthesis inhibitors. In A. R. Morrison \& P. L. Strick (Eds.), Changing concepts of the nervous system. New York: Academic Press, 1982.

RandT, C. T., Quartermain, D., Goldstein, M., \& Anagnoste, B. Norepinephrine biosynthesis inhibition: Effects on memory in mice. Science, 1971, 172, 498-499.

Sara, S. J., \& Remacle, J. F. Strychnine-induced passive avoidance facilitation after electro-convulsive shock or under training. Behavioral Biology, 1977, 19, 465-475.

Serota, R. G., Roberts, R. B., \& Flexner, L. B. Acetoxycycloheximide-induced transient amnesia: Protective effects of adrenergic stimulants. Proceedings of the National Academy of Sciences, 1972, 69, 340-342.

She arman, G., \& LAL, H. Discrimination stimulus properties of metrazol and bemegride: Some generalization and antagonism tests. Psychopharmacology, 1979, 64, 315-317.

Smiтh, C. B. Enhancement by reserpine and -methyldopa of the effects of d-amphetamine upon the locomotor activity of mice. Journal of Pharmacology and Experimental Therapeutics, 1963, 142, 343-349.

SPEAR, N. E. Retrieval of memories: A psychobiological approach. In W. K. Estes (Ed.), Handbook of learning and cognitive processes. Hillsdale, N.J: Erlbaum, 1976.

SPEAR, N. E. The processing of memories: Forgetting and retention. Hillsdale, N.J: Erlbaum, 1978.

Sternberg, D., \& Gold, P. E. Retrograde amnesia: Lack of attenuation with centrally administered adrenergic antagonists. Physiology \& Behavior, 1981, 27, 551-555.

Tulving, E., \& Thomson, D. M. Encoding specificity and retrieval processes in episodic memory. Psychological Review, 1973, 80, 352-373.

Wise, C. D., \& Stein, L. Amphetamine: Facilitation of behavior by augmented release of norepinephrine from the medial forebrain bundle. In E. Costa and S. Garattini (Eds.), Amphetamines and related compounds. New York: Raven Press, 1970.

(Manuscript received January 5, 1982; revision accepted for publication June 15, 1982.) 